\title{
HUMAN SERUM CHOLINESTERASE: VARIATIONS DURING PREGNANCY AND POST-PARTUM*
}

\author{
B. HAZEL, $\uparrow$ M.D., F.R.C.P.(C) AND D. Monier, M.D.
}

The CholdNeSterases CONSTITUte a family or a population of enzymes catalysing the hydrolysis of various cholinesters. The true or tissue cholinesterases are rather specific in their nature being mainly responsible for the hydrolysis of acetylcholine, the chemical transmitter of the nervous system. The serum cholinesterases have been shown to hydrolyse a large number of cholinesters as well as other esters such as benzoic acid derivatives and procaine and for these reasons are also known as pseudocholinesterases. They are found in tissues such as liver, skin, white matter of brain, heart, pancreas, and serum but their physiological function is still unknown. ${ }^{1}$

Succinyldicholine, a widely used muscular relaxant, is rapidly hydrolysed by serum pseudocholinesterases and in normal individuals produces a short period of apnea during which the anaesthetist proceeds with intubation. Prolonged periods of apnea have been reported in many patients after the administration of this drug as a result of a qualitative, genetically transmitted defect in the enzyme structure. A small number of investigators have also demonstrated that such an accident occurs in patients with only a small quantitative decrease in their total serum activity after the administration of cyclophosphamide ${ }^{2}$ or ecothiopate iodide eyedrops. ${ }^{3,4}$

Data published by Tourtelotte et al. ${ }^{5}$ Wetstone ${ }^{6}{ }^{6}$ Friedman,${ }^{7}$ Robertson, ${ }^{8}$ and Schnider ${ }^{9}$ indicate that pregnancy and the post-partum period are associated with a decline in serum cholinesterase activity. Henriquet et $a .^{10}$ and Rimbach and collaborators, ${ }^{11}$ using a test-paper method were unable to reproduce these results. However, one has to say that many of these studies were published when there was no suitable technique to determine the integrity of the enzymatic structure; while the others are assuming a normal molecule on the basis of normal dibucaine numbers.

In the last two years, this laboratory has been engaged in an extensive study of this molecular abnormality among the French-Canadian population of the province of Quebec. ${ }^{12}$ This publication will summarize the data obtained in 43 pregnant women and in 91 women tested on the second and third day following delivery as compared to a normal population composed of technologists and secretaries.

\section{Material and Methods}

Total serum cholinesterase activity was measured according to the method of Kalow et al. ${ }^{13,14}$ using benzoylcholine as substrate, slightly modified to be recorded

* This research was aided by Grant from the Medical Research Council of Canada (ma 3690 ). †Department of Medicine and Clinical Laboratories, Enzymology Section, Maisonneuve Hospital. Reprint request to B. Hazel, M.D., Maisonneuve Hospital, 5415 de L'Assomption Blvd., Montreal 410, P.Q. 
on a Unicam Spectrophotometer model sp-800 equipped with an automatic cell changer. The integrity of the enzyme molecule was verified by the addition in the assay system of 3 inhibitors (dibucaine, sodium fluoride, sodium chloride).

Dibucaine numbers (percentage of inhibition in presence of dibucaine) were determined according to the technique of Kalow and Genest, ${ }^{15}$ fluoride and chloride numbers by the methods of Harris and Whittaker. ${ }^{16,17}$

Enzyme activity is expressed in micromoles of benzoylcholine metabolized per hour at $37 \pm 0.2^{\circ} \mathrm{C}$ and each abnormal value represents the mean of three determinations.

\section{Results AND Discussion}

The quantitative changes occurring in total pseudocholinesterase activities during pregnancy as well as on the second and third day following delivery are illustrated in Figure 1. As compared to normal values of $104.34 \pm 24.39$ micromoles per hour, the state of pregnancy is associated with a statistically significant decrease $(p<0.02)$ in pseudocholinesterase levels which reached 82.43 \pm 20.12 . Delivery did not alter the serum level as indicated by values of $75.42 \pm 21.22$ on the second day post-partum and of $71.54 \pm 20.59$ on the third day.

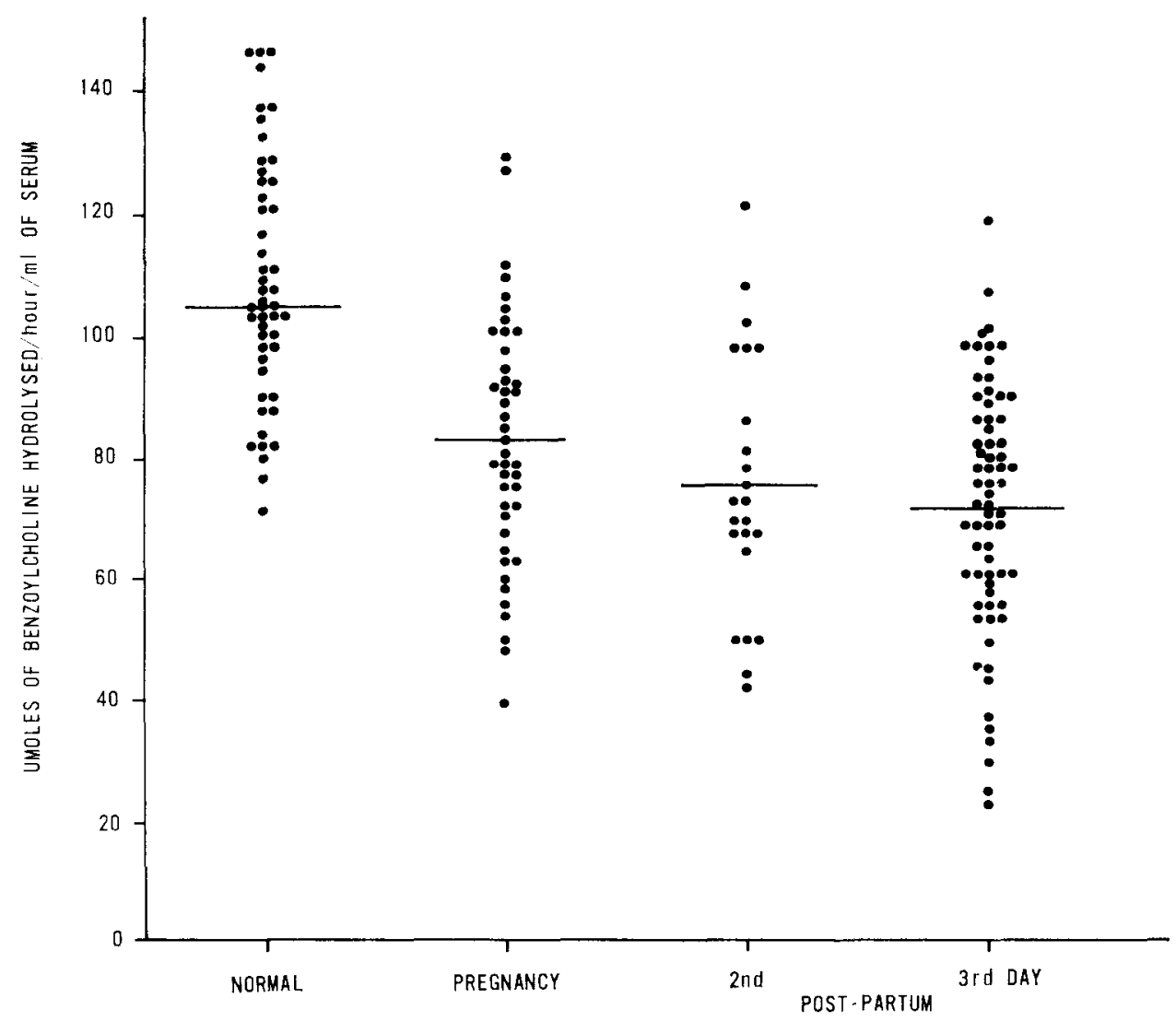

Figure 1. Total serum pseudocholinesterase activity measured in 47 normal, 43 pregnant, 91 women during the early post-partum period. 


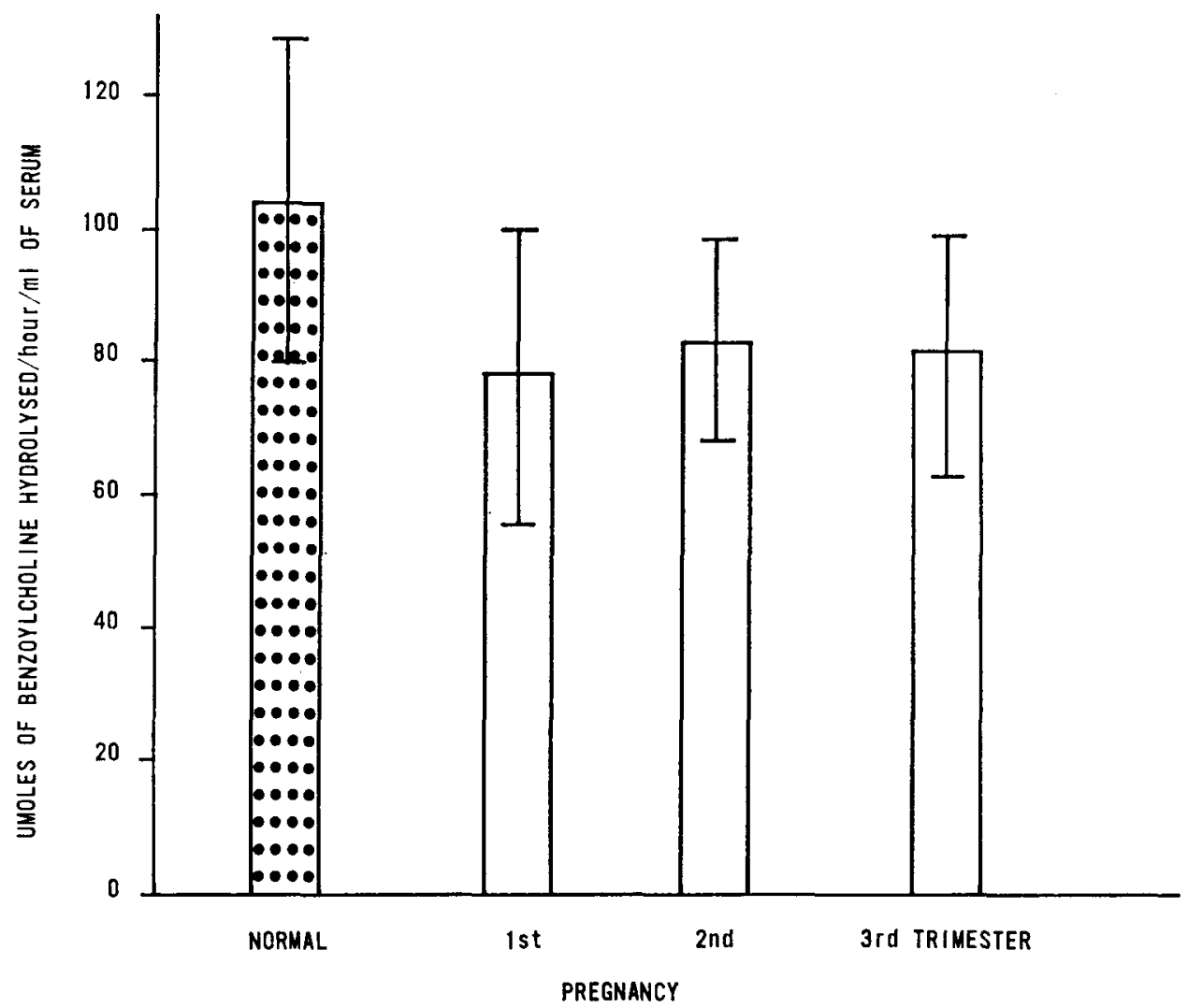

FIGURE 2. Variations of pseudocholinesterase activity during the course of pregnancy. Each column represents the Mean \pm Standard Deviation.

These data also indicate that among the normal control group only $2 / 47$ women or 4.3 per cent had serum values below the 1 standard-deviation limit, as compared to $18 / 43$ or 41.9 per cent among the pregnant women and $15 / 23$ or 65.2 per cent on the second day and $42 / 68$ or 64.8 per cent on the third day post-partum. Since many authors accept the possibility of prolonged apnea following the injection of succinylcholine in persons having only a quantitatively decreased serum pseudocholinesterase activity without any evident structural alteration, these women represent a potential anaesthetic hazard which requires further clinical investigation.

Figure 2 illustrates clearly that the decline in total enzymatic activity takes place during the first trimester of any pregnancy and also that the serum levels remain fairly stable during the second and third trimester. With the present available techniques, we are now able to state that this reduced enzymatic activity is not associated with DN, FN and ClN values statistically different from those of the control group (Table I).

Since experimental data have shown that many tissue enzyme populations decrease with aging, leading to a diminution in the total enzymatic activity measured in vitro, the data collected during this study were divided into 3 groups: pregnant 
TABLE I

Comparison of the Dibucaine, Flcoride, and Chloride Numbers in Normal and Pregnant Women

\begin{tabular}{lccccc}
\hline \hline & No & ClN & FN & DN & BCh \\
\hline $\begin{array}{l}\text { Normal } \\
\text { Pregnant }\end{array}$ & $(24)$ & $15.00 \pm 4.60$ & $59.00 \pm 2.26$ & $82.18 \pm 2.85$ & $\begin{array}{r}104.34 \pm 24.39 \\
\text { Trimester }\end{array}$ \\
$\quad(43)$ & & & & $82.43 \pm 20.12$ \\
1st & $(15)$ & $16.28 \pm 3.20$ & $57.63 \pm 2.67$ & $82.93 \pm 3.85$ & $78.51 \pm 22.76$ \\
2nd & $(15)$ & $13.82 \pm 4.68$ & $58.89 \pm 2.17$ & $82.04 \pm 3.24$ & $82.63 \pm 15.94$ \\
3rd & $(10)$ & $13.98 \pm 4.12$ & $58.38 \pm 2.49$ & $83.54 \pm 2.96$ & $81.10 \pm 18.61$ \\
\hline
\end{tabular}

women less than twenty years of age, those between twenty and thirty, and those over thirty. No significant difference could be demonstrated as shown in Figure 3.

If the pregnant group is divided according to the number of pregnancies (Figure 4) one sees that serum pseudocholinesterase activity of women bearing their first child is decreased to levels comparable to multiparous women, indicating that the diminution of enzymatic activity is associated with the state of pregnancy but has nothing to do with phenomena such as antibody production since one would expect titers to increase or to vary with consecutive pregnancies with some repercussions on the pseudocholinesterases levels.

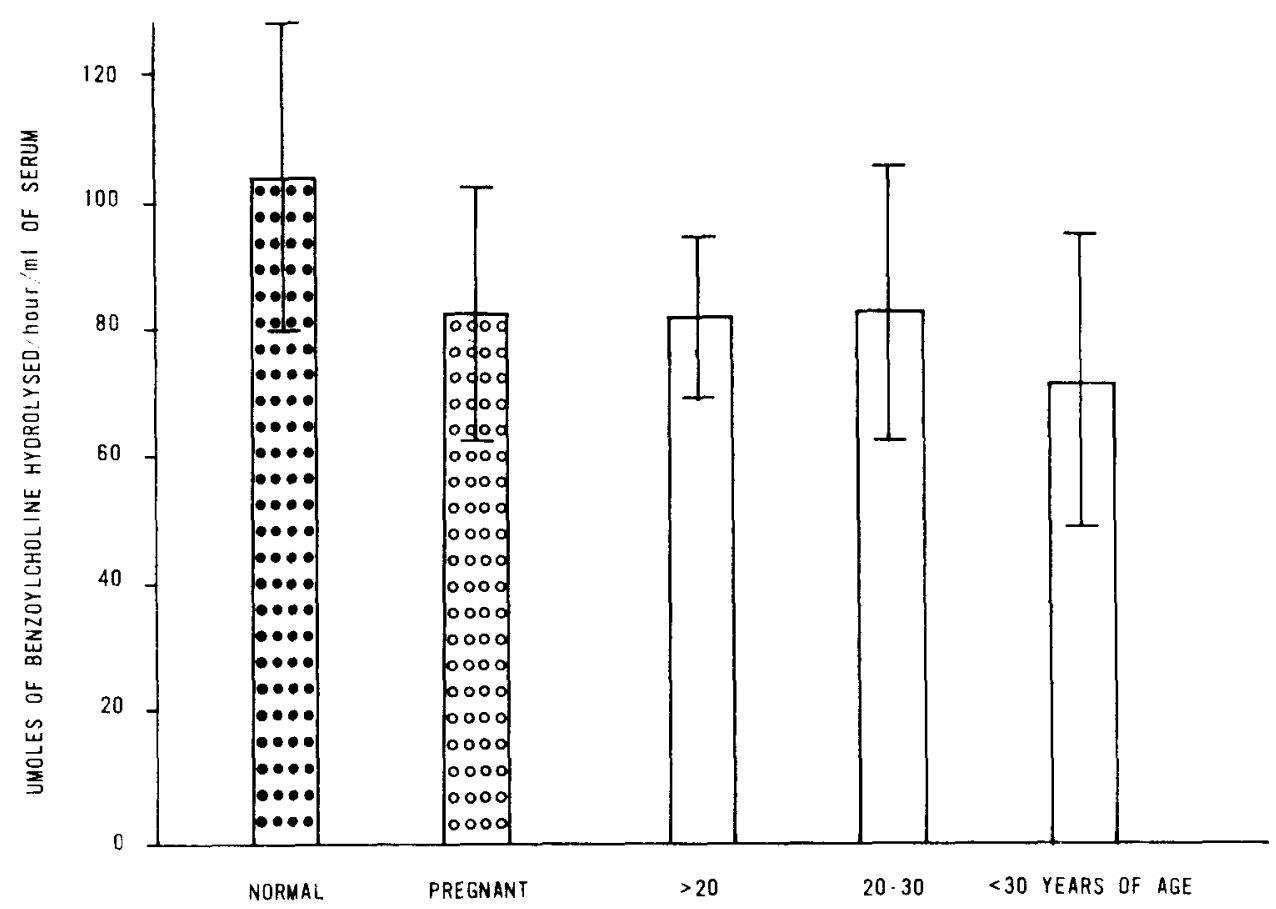

Figlre 3. Variations of pseudocholinesterase activity among pregnant women of different age groups. 


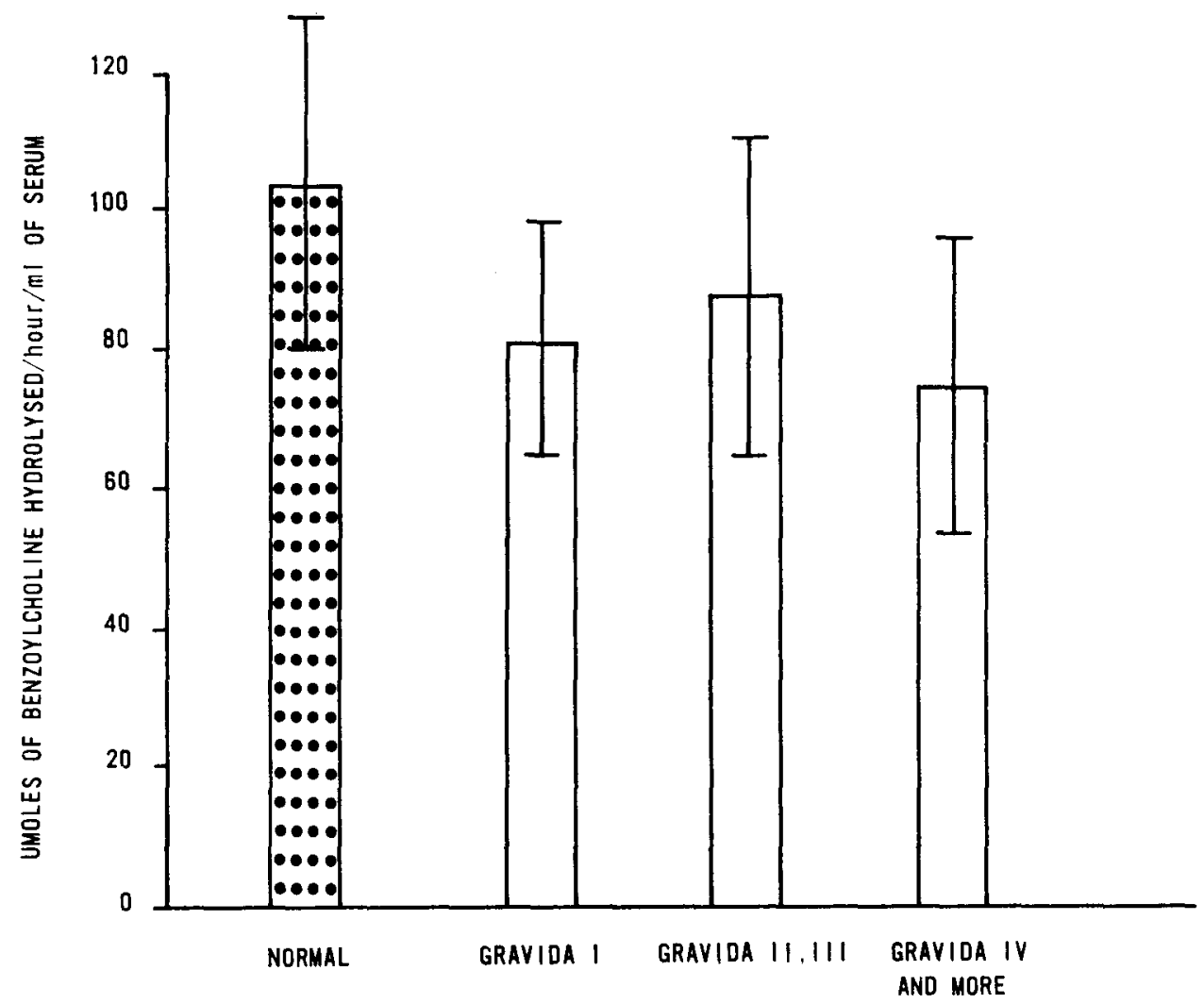

Frgure 4. Variations of human serum cholinesterase according to the number of pregnancies.

\section{SUMMARY}

In conclusion, the data presented indicate that pregnant women of any age, during the course of any pregnancy or the early post-partum period have significant lower serum cholinesterase activity. With the currently available techniques we were able to demonstrate that this decline is not associated with any structural malformation of the enzyme molecule.

\section{RÉSUMÉ}

Nos travaux démontrent que la grossesse et le post-partum immédiat sont associés à une diminution, statistiquement valable, des taux sériques de pseudocholinestérases. Cette baisse d'activité apparaît dès le premier trimestre, quel que soit l'âge de la parturiente, et que la patiente soit nullipare ou multipare. Grâce aux techniques de Kalow, Whittaker, nous pouvons cependant affirmer que cette baisse d'activité ne s'accompagne d'aucune modification de la structure moléculaire de l'enzyme.

\section{ACKNOWLEDGMENTS}

The authors wish to acknowledge the skillful technical assistance of $\mathrm{Mr}$. Jacques Longpré and Miss Jocelyne Marquis. 


\section{REFERENCES}

1. Lehmann, H. \& Liddell, J. Genetical variants of human serum pseudocholinesterase. Prog. Med. Genet. 3: 75-105 (1964).

2. Mone, James G. Qualitative and quantitative defects of pseudocholinesterase activity. Anaesthesia. 22: 55-68 (1967).

3. Pantuck, EugÈne J. Ecothiopate iodide eye drops and prolonged response to suxamethonium. Brit. J. Anaesth. 38: 406-407 (1966).

4. Birks, D. A.; Prior, V. J.; Silk, E.; \& Whittaker, M. Ecothiopate iodide treatment of glaucoma in Pregnancy. Arch. of Ophthalmology. 79: 283-285 (1968).

5. Tourtelotte, W. W. \& Odell, L. D. Plasma acetylcholinesterase activity. Am. J. Obstet. Gynec. 60: 1343 (1950).

6. Wetstone, H. J.; LaMotta, R. V.; Middlebrook, L.; Tennant, R.; \& White, B. V. Studies of cholinesterase activity. Iv: Liver function in pregnancy: values of certain standard liver function tests in normal pregnancy. Amer. J. Obstet. Gynec. 76: 480 (1958).

7. Friedman, M. M.; Lapan, B.; \& Taylor, T. H. Variations of enzyme activities during normal pregnancy. Amer. J. Obstet. Gynec. 82: 132 (1961).

8. Robertson, G. S. Serum cholinesterase deficiency. II. Pregnancy. Brit. J. Anaesth. 38: 361-369 (1966).

9. SHNider, S. M. Serum cholinesterase activity during pregnancy, labor and the puerperium. Anesthesiology, 26: 335-339 (1965).

10. Henriquet, F. Relation between cholinesterase and succinylcholine in anaesthesia. Minerva anest. 28: 393 (1962).

11. Rimbach, E. \& Dacic, Z. Serum cholinesterase in normal pregnancy, postpartum period, and during puerperium. Zbl. Gynäk. 85: 711 (1963).

12. Hazel, B.; Monier, D.; Trempe, L.; Beauchemin, M.; \& Rondeau, Y. Apnée à la succinyldicholine: étude d'une population canadienne-française. Canad. Anaesth. Soc. J. 17: 12-24 (1970).

13. Kalow, W. \& Lindsay, H. A. Comparison of optical and manometric methods for the assay of human serum cholinesterase. Canad. J. Biochem. Physiol. 33: 568 (1955).

14. Kalow, W. \& Lindsay, H. A. Kinetic studies on the hydrolysis of benzoyl choline by human serum cholinesterase. Canad. J. Biochem. Physiol. 34: 637 (1956).

15. Kalow, W. \& Genest, K. Method for the detection of atypical forms of human serum cholinesterase. Determination of Dibucaine numbers. Canad. J. Biochem. Physiol. 35: 339 (1957).

16. Harris, H. \& Whittaker, M. Differential inhibition of human serum cholinesterase with fluoride: recognition of two new phenotypes. Nature. 191: 496 (1961).

17. Harrris, H. \& Whittaken, M. Differential inhibition of "usual" and "atypical" serum cholinesterase by sodium chloride and sodium fluoride. Ann. Human Genet. 27: 52 (1963). 